\title{
Assessment of Metal Pollution of Soil and Diagnostic Species Associated with Oil Spills in the Niger Delta, Nigeria
}

\author{
Paul O. Fatoba, Clement O. Ogunkunle, and Cynthian O. Ihaza \\ Environmental Biology Unit, Department of Plant Biology, University of Ilorin, Nigeria \\ Corresponding author: \\ Clement O. Ogunkunle, Environmental Biology Unit, Department of Plant Biology, P. M. B. 1515, University of \\ Ilorin, 240003 Nigeria \\ E-mail:seyeogunkunle@gmail.com (ogunkunle.co@unilorin.edu.ng)
}

(received in June 2015; accepted in July 2015)

\begin{abstract}
An ecological impact assessment of crude-oil spills was carried out on the environment of an oil-rich community in the Niger Delta of Nigeria. Samples of the topsoil $(0-15 \mathrm{~cm})$, subsoil $(15-25 \mathrm{~cm})$ and the dominant species Gamba grass (Andropogon gayanus) were collected using the transect method from the point of spills. The samples were also collected from an unimpacted location (control). The samples were wet-digested and the concentrations of $\mathrm{Pb}, \mathrm{Cd}, \mathrm{Cu}$, and $\mathrm{Zn}$ were determined by flame atomic absorption spectrophotometry, while the physico-chemical properties of the topsoil were determined by standard methods. The data were subjected to Student $t$ test, ANOVA and Pearson correlation analysis, and the models for pollution assessment were employed to assess the pollution status of the soil and plant species. The results showed that concentrations of $\mathrm{Pb}, \mathrm{Cu}$ and $\mathrm{Zn}$ in the topsoil exceeded international standards at close proximity to point of spills $(0-200 \mathrm{~m})$, while Cd concentrations exceeded the international standard at all the locations. Only $\mathrm{Cd}$ exceeded the international standard in the subsoil. Contamination $\left(P_{i}\right)$ and integrated pollution $\left(P_{c}\right)$ indices of the topsoil showed reducing trends from the point of pollution, and locations at $0 \mathrm{~m}$ and $100 \mathrm{~m}$ exhibited high $P_{c}$, while those at $200 \mathrm{~m}$ showed moderate $P_{c}$ by all metals. The levels of $\mathrm{Pb}$ and $\mathrm{Cd}$ in the diagnostic species exceeded the World Health Organization limits and the pollution load index (PLI) portrayed severe contamination. In conclusion, the impact of crude-oil spills in the area was significant; soil remediation is important to avert ecological and human health disasters. Moreover, these findings will be useful for designing strategic measures for environmental control in the area.
\end{abstract}

Keywords: oil spillage, integrated pollution index, soil remediation, pollution load index.

\section{Introduction}

In the quest for industrialisation and greater economic empowerment, many developing countries, including Nigeria, have interfered with the environment to the extent that there is currently widespread environmental degradation and devastation with attendant climatic, economic and health effects. Since the beginning of petroleum production in Nigeria in 1958, many documents are available on the petroleum spills into agricultural lands through petroleum production operations (Odu et al., 1985; Imoobe \& Iroro, 2009). Although, the petroleum industry has contributed immensely to the economy and development of Nigeria, oil exploration, transportation and marketing operations have also presented some attendant negative impacts on the environment. Ozurumba (1999) showed that in 1999 alone about 47 major oil spillages due to vandalisation occurred in Nigeria resulting in damage to lives, plants and animals. Between 1976 and 1996, Gideon \& Josephine (2008) reported that over 647 spillages occurred spilling 2,369,407.04 barrels of crude oil with only $549,060.38$ barrels $(23 \%)$ being recovered, while $1,820,410.50$ barrels $(77 \%)$ were lost to the environment. The cause of these serious spillages was attributed to blowouts, sabotage, corrosion of pipelines, equipment failure, operator or maintenance error, third party accelerant, natural spills and misery spills (Imoobe \& Iroro, 2009). Ekundayo \& Obuekwe 
(2000) indicted oil spills for the introduction of heavy metals such as $\mathrm{Cu}, \mathrm{Ni}$ and $\mathrm{Hg}$ into the soil, which impair the biota due to their toxicity. Oil spill affects the physical-chemical properties of the soil, such as temperature, structure, nutrient status and $\mathrm{pH}$. The effects of heavy metal pollution may be immediate if crops planted in spill sites which have accumulated the metals are consumed by man and livestock.

Okordia and Oya in Ikarama community are hosts to Agip and Shell companies, but very little has been documented with respect to the impact of their activities on immediate environment. Based on this, the community needs to be environmentally audited from time to time so as to advise the stakeholders in the petrochemical industries, the government and the local communities on the potential health risks posed by the oil industry. Several studies have also indicated that metal pollution (e.g. $\mathrm{Pb}, \mathrm{Cd}$ and $\mathrm{Ni}$ ) is responsible for certain diseases of humans and animals (Gustav, 1974; Nolan, 2003; Young, 2005); and thus, there is a need for cleaning up oil-contaminated soil. So far, phytoremediation has proved to be cheaper and sustainably feasible in cleaning up pollutants from the soil (Joner et al., 2004). Hence, identification of plants growing in oil-spill impacted land with potentials to accumulate metals is imperative in order to establish suitable plants for the clean-up of metals in oil-spill impacted locations. Therefore, this study was undertaken to investigate the impact of oil spill on the soil and vegetation of this oil-rich community with respect to their heavy metal loads.

\section{Materials and methods \\ 2.1 Study area}

The study sites Okordia and Oya are in Ikarama $\left(05^{\circ} 09^{\prime} 16^{\prime \prime} \mathrm{N}, \quad 06^{\circ} 27^{\prime} 11 \mathrm{E}\right)$, a small community situated within Yenogoa Local Government Area, Bayelsa State, Nigeria (Figure 1). Bayelsa state is strategically located at the centre of the Niger Delta region of Nigeria, which is one of the richest wetlands in the world with a tropical climatic condition of a rainy season (April to November) and a dry season (December to March) and an annual rainfall ranging between 1,500 and 4,000 mm (Kuruk, 2004). Ikarama community is a host to Nigeria's Agip Oil Company and Shell Petroleum Development Company (SPDC). The SPDC pipelines linking Delta, Bayelsa and River states in Nigeria pass through Ikarama community and oil spills from equipment failure have been reported to be the major environmental contamination of this community (MOEN, 2008). The 2 study sites were chosen because of the frequent occurrence of oil spills in the sites. For example, 421 crude oil spills occurred between 18 December 1991 and 23 August 2008 in the state, while 9 major oil spills occurred within Ikarama community (MOEN, 2008). Moreover, more recent crude oil spills also occurred in December 2008 and June 2009 in Oya and Okordia, respectively.

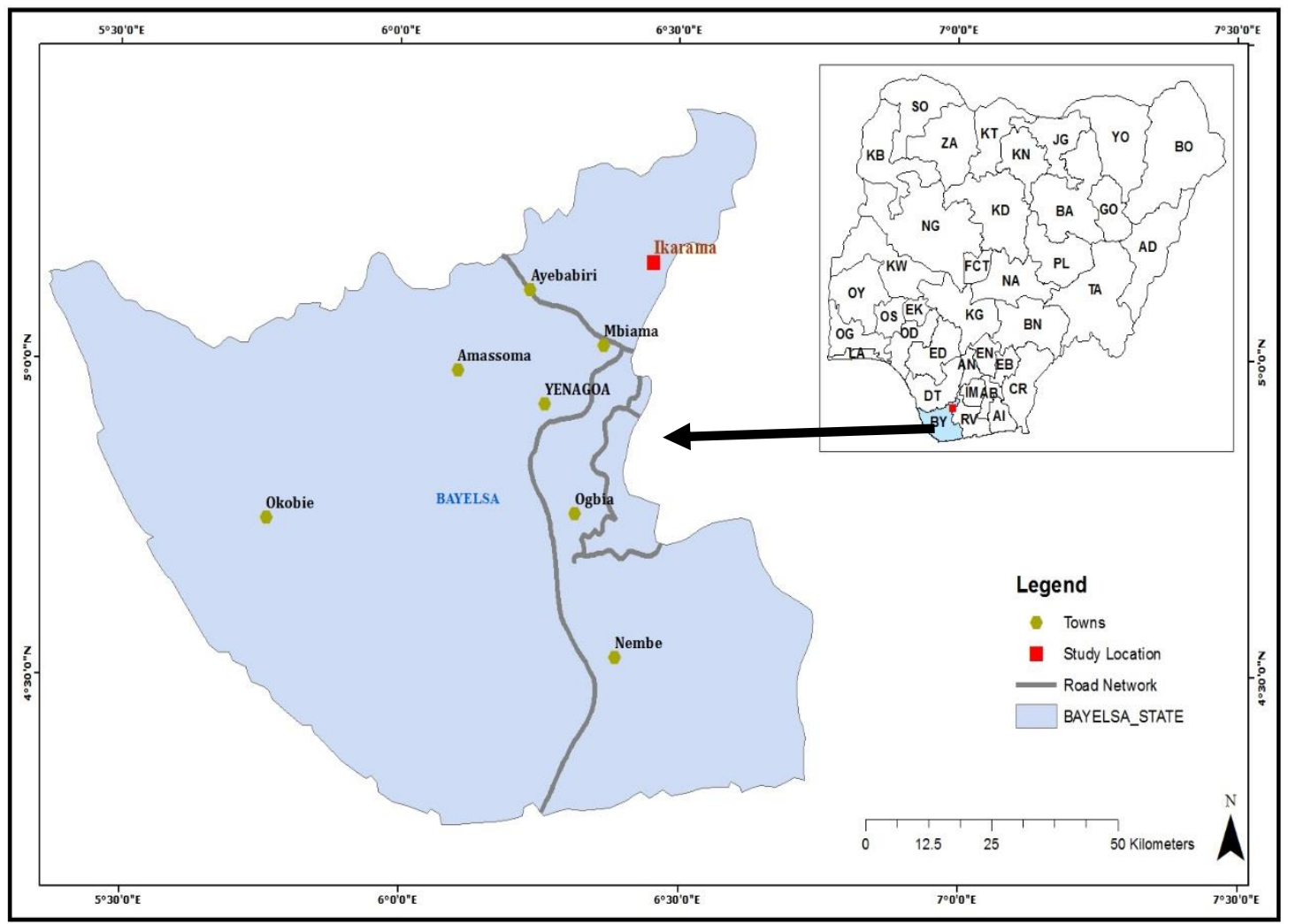

Figure 1. Map of Bayelsa state showing Ikarama community where the 2 study sites are located. Inset: Map of Nigeria showing different states. 


\subsection{Sampling and chemical analysis}

Soil and plant samples were collected from 2 oilspill impacted sites at Okordia and Oya and the sampling activities were carried out in September 2009. At each crude-oil impacted site, a line transect was set from the centre point of the spill in any accessible direction and soil samples were collected at every $100 \mathrm{~m}$ along the transect to a distance of $400 \mathrm{~m}$. The short transect distance was premised on the fact that most of the area was inundated with seawater. At every sampling point, 5 soil samples were randomly collected from the depth of $0-15 \mathrm{~cm}$ and $15-25 \mathrm{~cm}$, respectively (topsoil and subsoil, respectively), with a stainless soil auger, and a total of 50 soil samples (25 samples each of topsoil and subsoil) were collected in each site. The dominant plant species - Gamba grass (Andropogon gayanus) - was sampled at every point of soil collection in the 2 sites, while the samples that served as the control were collected at Zarama, a location that has not experienced crude oil spill. Roots of the samples were discarded at the site and the shoots were properly packed in a paper bag and labelled for laboratory analysis.

The soil samples were air-dried at room temperature, sieved through a $2-\mathrm{mm}$ mesh and ground into fine powder. One (1) $\mathrm{g}$ of the soil sample was wetdigested using the Aqua regia method described by ISO (2002). The resulting digestate was filtered using Whatman No 42 filter paper into a beaker and diluted with deionised water to make up $25 \mathrm{~mL}$. Four metal concentrations $(\mathrm{Pb}, \mathrm{Cd}, \mathrm{Cu}$, and $\mathrm{Zn}$ ) were determined by flame atomic absorption spectrophotometer (Bulk Scientific 210VGP, USA). One (1) g of the powdered plant sample was digested in $10 \mathrm{~mL}$ of conc. $\mathrm{HNO}_{3}$ on a hot plate until fumes turned white. The solution was filtered using Whatman No 42 filter paper and analysed for $\mathrm{Pb}, \mathrm{Cd}, \mathrm{Cu}$ and $\mathrm{Zn}$ using the FAAS (Bulk Scientific 210VGP, USA).

Procedural blanks and replicates' digestion were carried out for QA/QC. A calibration graph for each element determined by the AAS was drawn by using a series of working standard solutions (CPI International, USA) and correlation coefficients greater than 0.850 were obtained for all the elements. The soil $\mathrm{pH}$ was determined in a soil-deionised water suspension $(1: 2.5 \mathrm{w} / \mathrm{v})$ by a calibrated $\mathrm{pH}$ meter (PHS3C model); electrical conductivity (EC) was determined using a conductivity bridge (Hanna EC214 model) and soil particle size fractions were determined by the method of Bouyoucos (1962).

\subsection{Statistical analyses and assessment of metal pollution}

The data generated were subjected to the analysis of variance (ANOVA) and the means were separated with Duncan multiple range test (DMRT) using the Statistic Package for Social Sciences (SPSS) and Excel 2007 for Windows version 16. Student $t$ test was employed to test a significant difference between the metal in the soil and the diagnostic plant, while Pearson coefficient of correlation was used to determine the relationship between the metal in the soil and the plant at $p<0.05$, respectively.

Heavy metal pollution of the soil was assessed by the use of the contamination index $\left(P_{i}\right)$ and integrated contamination index $\left(P_{c}\right)$ models suggested by Huang (1987). The expression for the models is represented in Equations 1-4 and the applied threshold values $\left(\mathrm{mg} \mathrm{kg}^{-1}\right)$ are presented in Table 1 .

$$
\begin{aligned}
P_{i} & ={ }^{\mathrm{C}} / \mathrm{X}_{a} \quad\left[C_{i} \leq \mathrm{X}_{a}\right] \\
P_{i} & =1+\left\lceil\mathrm{C}^{\mathrm{C}}-\mathrm{X}_{a} / \mathrm{X}_{b}-\mathrm{X}_{a}\right\rceil\left[X_{a}<C_{i} \leq X_{b}\right] \\
P_{i} & =2+\left\lceil\mathrm{C}^{\mathrm{C}}-\mathrm{X}_{b} / \mathrm{X}_{c}-\mathrm{X}_{b}\right\rceil\left[X_{b}<C_{i} \leq X_{c}\right] \\
P_{i} & =3+\left\lceil^{\mathrm{C}_{i}-\mathrm{X}_{c}} / \mathrm{X}_{c}-\mathrm{X}_{b}\right\rceil\left[C_{i}>X_{c}\right]
\end{aligned}
$$

where $\mathrm{C}_{\mathrm{i}}$ is the metal concentration in the soil; $X_{a}$ is the bo-pollution threshold value; $X_{b}$ is the lowly polluted threshold value and $X_{c}$ is the highly polluted value. The threshold values of $X_{a}, X_{b}$ and $X_{c}$ are defined in Table 1 based on the Chinese Environmental Quality Standard for soils (SETAC, 1995).

The integrated contamination index $\left(P_{c}\right)$ for each study distance was calculated by the following formula:

$$
\mathrm{P}_{c}=\sum_{i=1}^{n}\left(\mathrm{P}_{i}-1\right)
$$

The classes of $P_{i}$ and $P_{c}$ according to Huang (1987) are presented in Table 2.

Table. 1. Threshold values $(\mathrm{mg} / \mathrm{kg})$ for contamination index $\left(P_{i}\right)$ (SETAC, 1995).

\begin{tabular}{||c|c|c|c|c|}
\hline & $\mathbf{P b}$ & $\mathbf{C d}$ & $\mathbf{C u}$ & $\mathbf{Z n}$ \\
\hline$X_{a}$ & 35 & 0.2 & 35 & 100 \\
\hline$X_{b}$ & 250 & 0.3 & 50 & 200 \\
\hline$X_{c}$ & 500 & 1.0 & 400 & 500 \\
\hline
\end{tabular}

Table 2. Classes of contamination index $\left(P_{i}\right)$ and integrated pollution index $\left(P_{c}\right)$ (Huang, 1987; D'Souza et al., 2013).

\begin{tabular}{||c|c|c||}
\hline Class & $\begin{array}{c}\text { Contamination } \\
\text { index }\left(\boldsymbol{P}_{\boldsymbol{i}}\right)\end{array}$ & $\begin{array}{c}\text { Integrated } \\
\text { pollution index }\left(\boldsymbol{P}_{\boldsymbol{c}}\right)\end{array}$ \\
\hline No & $P_{i} \leq 1$ & $P_{c} \leq 0$ \\
\hline Low & $1 \leq P_{i} \leq 2$ & $0<P_{c} \leq 7$ \\
\hline Moderate & $2 \leq P_{i} \leq 3$ & $7<P_{c} \leq 21$ \\
\hline High & $P_{i}>3$ & $P_{c}>21$ \\
\hline
\end{tabular}

The heavy metal pollution status of the diagnostic species was assessed using the contamination factor (CF) and the pollution load index (PLI) suggested by Fernandez \& Carballeira (2001) and Kalavrouzioti et al. (2012), respectively:

$$
C F=C_{m} / C_{b}
$$

where $C_{m}$ is concentration of the metal determined in the plant species; $C_{b}$ is concentration of the metal determined in the control. 
$\mathrm{CF}<1$ - showed no contamination (NC); $1<\mathrm{CF}<2 \quad-$ suspected contamination (SC); $2<\mathrm{CF}<3.5-$ slight contamination (SLC); $3.5<\mathrm{CF}<8-$ moderate contamination (MC); $8<\mathrm{CF}<27$ - severe contamination (SEC); and $\mathrm{CF}>27$ - extreme contamination (EC) (GonzalezMiqueo et al., 2010).

$$
P L I=n \sqrt{\sum_{i=1}^{n} C F_{1} \times C F_{2} \times C F_{n}}
$$

Values of PLI close to 1 indicate that elemental loads of plant species are near to the background level, PLI 1-3 shows moderate pollution, and values > 3 indicate severe pollution (Daud et al., 2006).

\section{$3 \quad$ Results and discussion}

\subsection{Level of heavy metals in topsoil and subsoil}

The characteristics of the topsoil in the study sites are presented in Table 3. The topsoil was predominantly sandy with less than $2 \%$ silt and $8 \%$ clay and acidic. The sandy portions were found to constitute more than $90 \%$ of the topsoil in Okordia and Oya. The $\mathrm{pH}$ values of the soil ranged from 4.66 to 5.6 and from 4.09 to 4.76 for Okordia and Oya, respectively, showing that the soils were acidic. Increased acidity has been reported to enhance mobility, solubility and availability of elements in soils (Odu et al., 1985; Sauve et al., 1997). The acidic nature of the soil of the area is not surprising because most of the soils in the south-south geographical zone of Nigeria are acidic and which may be due to their exposure to excessive precipitation leading to leaching of the basic cations and being replaced by hydrogen ion (Ngobiri et al., 2007). This finding was consistent with the reports of Osuji \& Nwoye (2007) as they also reported a $\mathrm{pH}$ range of 4.9-5.1 in crude-oil polluted soil and 5.6 in unpolluted soil. The electrical conductivity (EC) of the 2 oil-impacted sites range from 0.08 to $0.15 \mathrm{dS} / \mathrm{m}$ and from 0.07 to $0.18 \mathrm{dS} / \mathrm{m}$ for Okordia and Oya, respectively. The high EC observed in these impacted soils may be linked to the crude-oil spill, suggesting the presence of highly soluble solutes.

Table 3. Physico-chemical characteristics of topsoil of Okordia and Oya.

\begin{tabular}{||c|c|c|c|c|c|c||}
\hline & & \multicolumn{5}{|c||}{ Soil characteristics } \\
\hline Location & Distance (m) & Sand (\%) & Silt (\%) & Clay (\%) & pH (1:2.5) & EC (dS m-1) (1:2.5) \\
\hline Okordia & 400 & $93.07 \pm 1.79$ & $1.67 \pm 0.75$ & $5.27 \pm 2.54$ & $4.82 \pm 0.61$ & $0.08 \pm 0.05$ \\
\hline & 300 & $93.63 \pm 2.51$ & $0.60 \pm 0.20$ & $5.73 \pm 2.39$ & $5.06 \pm 0.90$ & $0.09 \pm 0.06$ \\
\hline & 200 & $91.60 \pm 2.21$ & $1.73 \pm 0.91$ & $6.67 \pm 2.75$ & $4.66 \pm 1.07$ & $0.08 \pm 0.03$ \\
\hline & 100 & $91.27 \pm 2.01$ & $1.77 \pm 0.93$ & $6.93 \pm 2.47$ & $5.09 \pm 0.77$ & $0.13 \pm 0.02$ \\
\hline & 0 & $93.43 \pm 2.68$ & $1.23 \pm 1.02$ & $5.17 \pm 2.79$ & $5.62 \pm 0.55$ & $0.15 \pm 0.03$ \\
\hline Oya & 400 & $87.57 \pm 3.19$ & $2.17 \pm 0.60$ & $6.93 \pm 2.11$ & $4.44 \pm 0.58$ & $0.07 \pm 0.01$ \\
\hline & 300 & $91.17 \pm 2.47$ & $1.63 \pm 0.95$ & $7.20 \pm 2.25$ & $4.76 \pm 1.09$ & $0.08 \pm 0.02$ \\
\hline & 200 & $91.90 \pm 1.45$ & $1.77 \pm 0.85$ & $6.33 \pm 1.59$ & $4.09 \pm 0.58$ & $0.09 \pm 0.03$ \\
\hline & 100 & $92.37 \pm 0.81$ & $1.73 \pm 0.91$ & $5.90 \pm 1.47$ & $4.69 \pm 1.34$ & $0.12 \pm 0.08$ \\
\hline & 0 & $91.73 \pm 1.05$ & $1.17 \pm 1.08$ & $7.10 \pm 1.37$ & $4.76 \pm 1.23$ & $0.18 \pm 0.01$ \\
\hline
\end{tabular}

Heavy metal contents of the topsoil of Okordia and Oya at various distances are shown in Table 4. It was evident that metal concentrations of the soil decreased significantly $(\mathrm{P}<0.05)$ as the distance increased from the point of the spill; and metal concentrations were consistently and significantly higher $(\mathrm{P}<0.05)$ at $0 \mathrm{~m}$.

Table 4. Heavy metal contents ( $\left.\mathrm{mg} \mathrm{kg}^{-1}\right)$ of topsoil of Okordia and Oya.

\begin{tabular}{|c|c|c|c|c|c|}
\hline Site & Distance (m) & \multicolumn{4}{|c|}{ Concentration (mean \pm SD) } \\
\hline & & $\mathbf{P b}$ & $\mathrm{Cd}$ & $\mathrm{Cu}$ & Zn \\
\hline Okordia & 400 & $19.7 \pm 2.4^{\mathrm{e}}$ & $5.1 \pm 0.25^{\mathrm{d}}$ & $18.7 \pm 0.7^{\mathrm{d}}$ & $181.3 \pm 17.2^{\mathrm{d}}$ \\
\hline & 300 & $23.7 \pm 1.1^{\mathrm{c}}$ & $5.9 \pm 0.35^{\mathrm{d}}$ & $21.6 \pm 0.8^{\mathrm{d}}$ & $185.3 \pm 15.0^{\mathrm{d}}$ \\
\hline & 200 & $41.0 \pm 6.2^{\mathrm{c}}$ & $7.0 \pm 0.6^{\mathrm{c}}$ & $37.3 \pm 7.6^{\mathrm{c}}$ & $201.0 \pm 34.6^{\mathrm{c}}$ \\
\hline & 100 & $88.2 \pm 4.2^{b}$ & $9.3 \pm 2.0^{b}$ & $82.0 \pm 18.5^{\mathrm{b}}$ & $223.7 \pm 38.1 \mathrm{a}^{\mathrm{b}}$ \\
\hline & 0 & $128.1 \pm 12.5^{\mathrm{a}}$ & $10.7 \pm 3.12^{\mathrm{a}}$ & $116.8 \pm 7.8^{\mathrm{a}}$ & $285.0 \pm 43.8^{\mathrm{a}}$ \\
\hline Oya & 400 & $19.8 \pm 4.9^{\mathrm{e}}$ & $5.2 \pm 0.2^{\mathrm{d}}$ & $19.8 \pm 0.8^{\mathrm{d}}$ & $184.6 \pm 16.0^{\mathrm{d}}$ \\
\hline & 300 & $23.3 \pm 6.5^{\mathrm{c}}$ & $2.2 \pm 0.2^{\mathrm{e}}$ & $22.6 \pm 1.4^{\mathrm{d}}$ & $190.7 \pm 16.8^{\mathrm{d}}$ \\
\hline & 200 & $34.0 \pm 8.2^{\mathrm{c}}$ & $6.7 \pm 3.1^{\mathrm{c}}$ & $32.7 \pm 8.8^{\mathrm{c}}$ & $221.7 \pm 38.4^{\mathrm{c}}$ \\
\hline & 100 & $82.5 \pm 23.3^{\mathrm{b}}$ & $9.2 \pm 2.7^{b}$ & $78.5 \pm 15.0^{\mathrm{b}}$ & $272.5 \pm 77.6^{\mathrm{b}}$ \\
\hline & 0 & $115.0 \pm 14.2^{\mathrm{a}}$ & $11.0 \pm 3.7^{\mathrm{a}}$ & $120.8 \pm 3.6^{\mathrm{a}}$ & $309.3 \pm 63.5^{\mathrm{a}}$ \\
\hline CCME $^{*}$ & & 70 & 1.4 & 63 & 200 \\
\hline
\end{tabular}

Values with the same superscript along the same column are not statistically different at $p \leq 0.05$.

* - CCME limits for metals in agricultural soils.

The concentrations of $\mathrm{Pb}, \mathrm{Cu}$ and $\mathrm{Zn}$ at $0 \mathrm{~m}$ doubled the concentrations at $300 \mathrm{~m}$ and $400 \mathrm{~m}$, whereas the concentrations of $\mathrm{Cd}$ were in several folds of metal concentrations at $300 \mathrm{~m}$. It is clear that the high concentrations of heavy metals in the topsoil up to $300 \mathrm{~m}$ distance in the 2 sites are resultant effects of 
the crude-oil spill. Essoka et al. (2006) reported high concentrations of $\mathrm{Pb}$ and $\mathrm{Cd}$ in the soil around a crudeoil polluted site in Warri, Delta state in Nigeria. Comparing the metal loads of the topsoil of the 2 crude-oil impacted areas with the limits stipulated for agricultural soil by the Canadian Council of Minister of Environment (CCME) (2007), it was observed that the concentrations of $\mathrm{Pb}$ and $\mathrm{Cu}$ in the topsoil exceeded CCME limits up to $100 \mathrm{~m}$ distance. Cd concentrations at the 2 sites were also several folds greater than the CCME limit, while $\mathrm{Zn}$ concentrations exceeded the CCME limit up to $200 \mathrm{~m}$ distance (Table 4).

These elevated values of heavy metals in the soil of Okordia and Oya of Ikarama suggest anthropogenic inputs into the soil due to several crude oil spillages in the area since more than 60 metals have been established to be in crude oil (Nduka et al., 2012). The fact that there is significant metal pollution in the area becomes ecologically significant due to the agrarian nature of the community and the possibility of toxic metals being transferred up the food chain, thereby portending human health hazards.

The heavy metal loads in the subsoil of Okordia and Oya are shown in Table 5. Generally, the concentrations of $\mathrm{Pb}, \mathrm{Cd}, \mathrm{Cu}$ and $\mathrm{Zn}$ in the subsoil were lower than the concentrations in the topsoil. The subsoil of the 2 sites was contaminated with $\mathrm{Cd}$ at all locations, while $\mathrm{Zn}$ contamination was up to $200 \mathrm{~m}$ when compared with the CCME limits. The same pattern of reduction of metal concentrations in the topsoil as the distance increases was also observed for the subsoil.

Table 5. Heavy metal content $\left(\mathrm{mg} \mathrm{kg}^{-1}\right)$ of subsoil of Okordia and Oya.

\begin{tabular}{||c|c|c|c|c|c||}
\hline Site & Distance (m) & \multicolumn{4}{|c||}{ Concentration (mean \pm SD) } \\
\hline & & Pb & Cd & Cu & Zn \\
\hline Okordia & 400 & $5.1 \pm 1.50^{\mathrm{d}}$ & $2.5 \pm 0.1^{\mathrm{d}}$ & $5.0 \pm 1.3^{\mathrm{c}}$ & $54.6 .1 \pm 6.8^{\mathrm{e}}$ \\
\hline & 300 & $4.8 \pm 0.37^{\mathrm{d}}$ & $2.8 \pm 0.1^{\mathrm{d}}$ & $5.6 \pm 0.7^{\mathrm{c}}$ & $185.3 \pm 4.12^{\mathrm{d}}$ \\
\hline & 200 & $6.3 \pm 1.1^{\mathrm{c}}$ & $3.0 \pm 0.2^{\mathrm{c}}$ & $7.3 \pm 1.0^{\mathrm{b}}$ & $201.0 \pm 33.6^{\mathrm{c}}$ \\
\hline & 100 & $8.8 \pm 1.7^{\mathrm{b}}$ & $3.6 \pm 0.1^{\mathrm{b}}$ & $8.8 \pm 0.8^{\mathrm{b}}$ & $223.7 \pm 38.1^{\mathrm{b}}$ \\
\hline & 0 & $11.0 \pm 1.0^{\mathrm{a}}$ & $3.8 \pm 0.1^{\mathrm{a}}$ & $12.3 \pm 0.2^{\mathrm{a}}$ & $277.2 \pm 43.8^{\mathrm{a}}$ \\
\hline Oya & 400 & $4.5 \pm 0.6^{\mathrm{d}}$ & $2.6 \pm 0.1^{\mathrm{e}}$ & $4.5 \pm 0.6^{\mathrm{d}}$ & $184.6 \pm 16.0^{\mathrm{d}}$ \\
\hline & 300 & $6.8 \pm 1.0^{\mathrm{c}}$ & $3.0 \pm 0.2^{\mathrm{c}}$ & $4.7 \pm 0.8^{\mathrm{d}}$ & $190.6 \pm 16.7^{\mathrm{d}}$ \\
\hline & 200 & $8.1 \pm 0.5^{\mathrm{b}}$ & $2.8 \pm 0.5^{\mathrm{d}}$ & $5.2 \pm 1.5^{\mathrm{c}}$ & $221.7 \pm 33.7^{\mathrm{b}}$ \\
\hline & 100 & $10.0 \pm 0.8^{\mathrm{a}}$ & $3.1 \pm 0.7^{\mathrm{b}}$ & $11.5 \pm 1.7^{\mathrm{b}}$ & $272.5 \pm 77.5^{\mathrm{a}}$ \\
\hline CCME & 0 & $10.8 \pm 0.5^{\mathrm{a}}$ & $3.5 \pm 0.3^{\mathrm{a}}$ & $13.6 \pm 1.7^{\mathrm{a}}$ & $209.2 \pm 63.2^{\mathrm{c}}$ \\
\hline
\end{tabular}

Values with the same superscript along the same column are not statistically different at $p \leq 0.05$.

\subsection{Level of heavy metals in the diagnostic species Andropogon gayanus}

The concentrations of metals in Andropogon gayanus (Gamba grass) used as biomonitor in this study are presented in Table 6. Generally, Gambia grass in the control had the lowest values of metals. The highest concentration of metals in the diagnostic plant was obtained at the point of the spill $(0 \mathrm{~m})$ and subsequently decreased significantly $(\mathrm{P}<0.05)$ away from the source point of pollution up to $300 \mathrm{~m}$ away. This reported reduction in metal concentration in the diagnostic plant as the distance increased from the source point of pollution has been earlier reported by Bada \& Olarinle (2012).

Table 6. Heavy metal content $\left(\mathrm{mg} \mathrm{kg}^{-1}\right)$ of Andropogon gayanus growing at various locations in the study sites.

\begin{tabular}{||c|c|c|c|c|c||}
\hline \hline & & \multicolumn{4}{|c||}{ Concentration (mean \pm SD) } \\
\hline Site & Distance (m) & $\mathbf{P b}$ & $\mathbf{C d}$ & $\mathbf{C u}$ & $\mathbf{Z n}$ \\
\hline Okordia & 400 & $4.5 \pm 1.25^{\mathrm{d}}$ & $0.25 \pm 0.05^{\mathrm{d}}$ & $4.1 \pm 0.05^{\mathrm{e}}$ & $8.0 \pm 0.12^{\mathrm{d}}$ \\
\hline & 300 & $3.5 \pm 0.25^{\mathrm{e}}$ & $0.5 \pm 0.25^{\mathrm{c}}$ & $5.6 \pm 0.64^{\mathrm{d}}$ & $7.8 \pm 0.37^{\mathrm{d}}$ \\
\hline & 200 & $4.2 \pm 0.12^{\mathrm{c}}$ & $0.75 \pm 0.25^{\mathrm{c}}$ & $6.5 \pm 0.12^{\mathrm{c}}$ & $16.1 \pm 0.37^{\mathrm{c}}$ \\
\hline & 100 & $4.7 \pm 0.12^{\mathrm{b}}$ & $1.2 \pm 0.07^{\mathrm{b}}$ & $7.7 \pm 0.02^{\mathrm{b}}$ & $27.2 \pm .75^{\mathrm{b}}$ \\
\hline & 0 & $6.3 \pm 0.25^{\mathrm{a}}$ & $3.5 \pm 1.5^{\mathrm{a}}$ & $9.0 \pm 0.12^{\mathrm{a}}$ & $31.7 \pm 4.25^{\mathrm{a}}$ \\
\hline Oya & 400 & $4.6 \pm 0.12^{\mathrm{d}}$ & $0.25 \pm 0.25^{\mathrm{e}}$ & $2.5 \pm 2.87^{\mathrm{e}}$ & $6.5 \pm 0.25^{\mathrm{d}}$ \\
\hline & 300 & $4.8 \pm 0.12^{\mathrm{d}}$ & $0.5 \pm 0.05^{\mathrm{d}}$ & $5.2 \pm 0.05^{\mathrm{d}}$ & $7.5 \pm 0.03^{\mathrm{c}}$ \\
\hline & 200 & $6.3 \pm 0.25^{\mathrm{b}}$ & $1.0 \pm 0.05^{\mathrm{c}}$ & $6.3 \pm 0.12^{\mathrm{c}}$ & $12.7 \pm 0.12^{\mathrm{b}}$ \\
\hline & 100 & $6.0 \pm 0.62^{\mathrm{c}}$ & $1.2 \pm 0.5^{\mathrm{b}}$ & $7.7 \pm 0.03^{\mathrm{b}}$ & $26.0 \pm 0.62^{\mathrm{a}}$ \\
\hline Control & 0 & $8.1 \pm 0.62^{\mathrm{a}}$ & $2.2 \pm 1.50^{\mathrm{a}}$ & $9.1 \pm 0.11^{\mathrm{a}}$ & $26.7 \pm 0.25^{\mathrm{a}}$ \\
\hline WHO limit & & $2.0 \pm 0.50$ & $0.2 \pm 1.00$ & $1.6 \pm 0.12$ & $4.0 \pm 0.12$ \\
\hline Phytotoxic level $^{\mathrm{a}}$ & & 2.0 & 0.2 & 10 & $\mathrm{n} . \mathrm{a}$. \\
\hline \hline
\end{tabular}

Values with the same superscript along the same column are statistically the same at $p \leq 0.05 ;{ }^{*}-$ WHO Permissible limit in plants; ${ }^{a}$ - Varun et al. (2010).

Compared with the WHO (1996) permissible limits of metals in plants, $\mathrm{Pb}$ and $\mathrm{Cd}$ exhibited elevated concentrations beyond the WHO limits at all locations. Ling et al. (2007) have asserted that heavy metal contamination of the soil may pose risks and hazards to humans through the food chain, which is 
soil-plant-human or soil-plant-animal-human, as well as reduction in food quality via phytotoxicity. Meanwhile, the concentrations of all the metals in $A$. gayanus were below the phytotoxic levels in plants as presented by Varun et al. (2010); and this could explain its continued survival in the presence of the elevated metal concentrations in the soil. There is also the possibility of A. gayanus being excluder of these heavy metals as the concentrations never reached phytotoxic levels despite their abundance in the soil of the area.

Student $t$ test used to compare the metal contents of the topsoil with the grass and the Pearson correlation coefficient are presented in Table 7. The concentrations of heavy metals in the topsoil positively and significantly correlated $(p<0.05)$ with the concentrations of metals in A. gayanus, except $\mathrm{Cd}$ at Oya. This indicates the possibility of A. gayanus taking up the heavy metals solely from the polluted topsoil. Metals in A. gayanus were significantly lower than their corresponding concentrations in the topsoil at $p<0.05$ (Table 7). This also evidently proves that high concentrations of metals in the soil do not always indicate similar high concentrations in plants; the extent of accumulation depends on plant and heavy metal species (Hart et al., 2005).

Table 7. Pearson correlation coefficients $(r)$ and Student $t$ test between metals in topsoil and Andropogon gyanus in the study sites.

\begin{tabular}{||c|c|c|c|c||}
\hline & \multicolumn{2}{|c|}{$\begin{array}{c}\text { Pearson correlation } \\
(\mathbf{r})\end{array}$} & \multicolumn{2}{c||}{ Student $\boldsymbol{t}$ test } \\
\hline Metal & Okordia & Oya & Okordia & Oya \\
\hline$P b$ & $0.725^{* *}$ & $0.844^{* *}$ & $4.790^{* *}$ & $0.808^{* *}$ \\
\hline$C d$ & $0.746^{* *}$ & 0.360 & $10.232^{* *}$ & $5.600^{* *}$ \\
\hline$C u$ & $0.908^{* *}$ & $0.828^{* *}$ & $4.703^{* *}$ & $4.566^{* *}$ \\
\hline $\mathrm{Zn}$ & $0.798^{* *}$ & $0.756^{* *}$ & $16.350^{* *}$ & $13.078^{* *}$ \\
\hline
\end{tabular}

\subsection{Pollution assessment of topsoil and diagnostic species}

The pollution assessment of the topsoil using the contamination index $\left(P_{i}\right)$ and the integrated pollution index $\left(P_{c}\right)$ is presented in Figure 2.
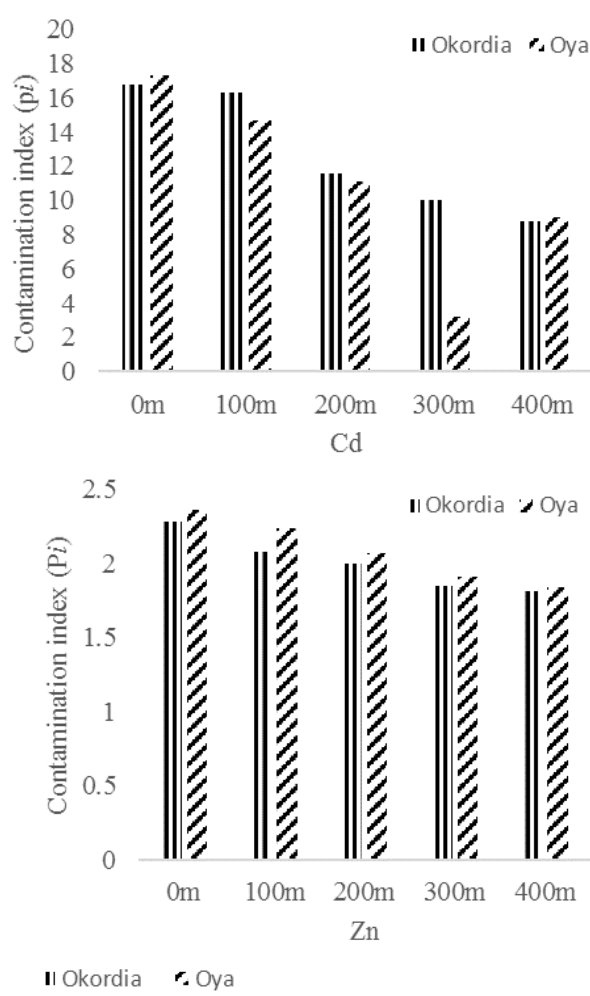

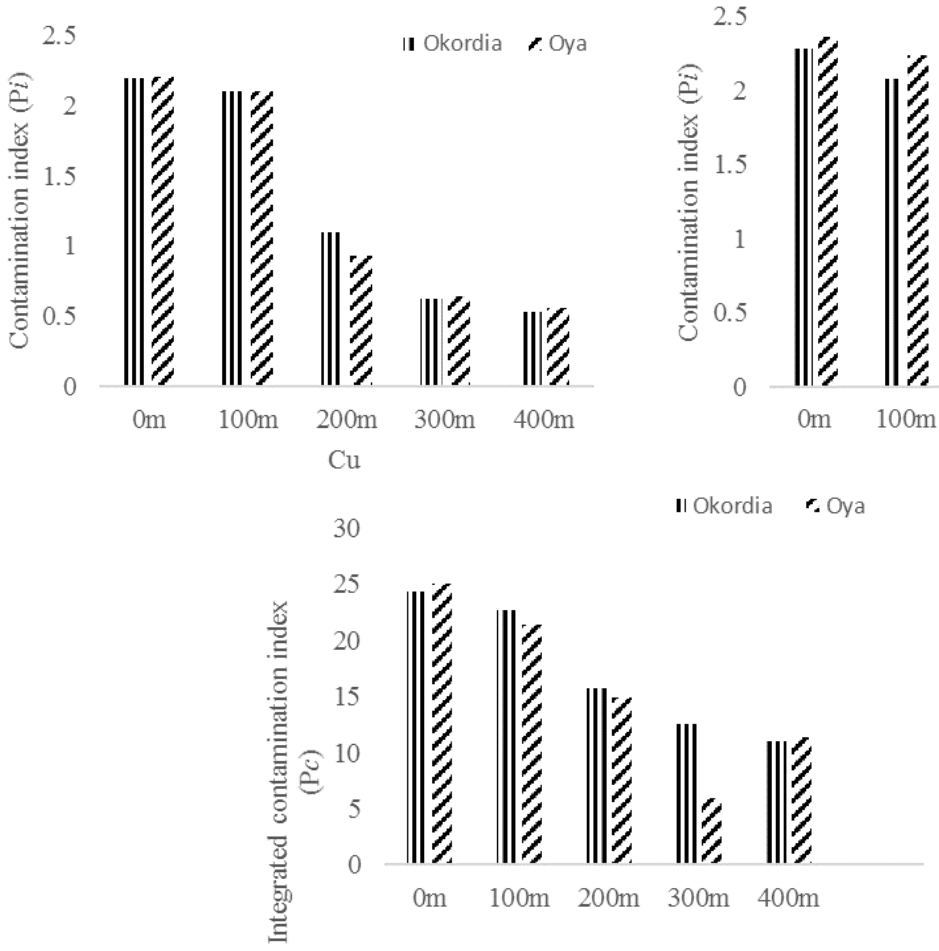

Figure 2. Contamination index $\left(P_{i}\right)$ of $(a) P b,(b) C d,(c) C u,(d) Z n$ and $(e)$ the integrated pollution index $\left(P_{c}\right)$ of the topsoil of the 2 study sites. 
Low contamination by $\mathrm{Pb}\left(1 \leq P_{i}<2\right)$ was observed in the topsoil of Okordia and Oya from $0 \mathrm{~m}$ to $200 \mathrm{~m}$ distance whereas $300 \mathrm{~m}$ and $400 \mathrm{~m}$ locations showed no contamination $\left(P_{i} \leq 1\right)$. High levels of contamination $\left(P_{i}>3\right)$ were recorded in the case of $\mathrm{Cd}$ across all locations. The sites showed moderate contamination $\left(2 \leq P_{i} \leq 3\right)$ of $\mathrm{Cu}$ and $\mathrm{Zn}$ at $0 \mathrm{~m}$ and $200 \mathrm{~m}$, while low contamination of $\mathrm{Zn}$ was observed from $200 \mathrm{~m}$ to $400 \mathrm{~m}$ in the 2 sites. $\mathrm{Pb}$ and $\mathrm{Cu}$ indicated no contamination from $200 \mathrm{~m}$ to $400 \mathrm{~m}$ in the 2 sites. It is noteworthy that the contamination levels in the 2 sites for all the metals showed a reducing trend from the source of pollution, and $\mathrm{Cd}$ was consistently at high levels across the locations.

The integrated contamination index $\left(P_{c}\right)$ values of the locations for the 2 sites are presented in Figure $2 \mathrm{f}$. The same reducing trend of the contamination index $\left(P_{i}\right)$ observed at the 2 sites was also represented in the integrated contamination index $\left(P_{c}\right)$. High integrated $\left(P_{c}>21\right)$ contamination was observed at $0 \mathrm{~m}$ and $100 \mathrm{~m}$ at the 2 sites due to their proximity to the source of pollution. Locations at $200 \mathrm{~m}, 300 \mathrm{~m}$ and $400 \mathrm{~m}$ in Okordia and locations at $200 \mathrm{~m}$ and $400 \mathrm{~m}$ in Oya indicated moderate integrated contamination $(7<$ $\left.P_{c} \leq 21\right)$. The location at $300 \mathrm{~m}$ in Oya indicated low integrated contamination $\left(0<P_{c} \leq 7\right)$. It is clear from the results that all the locations within the 2 sites does not fall within the threshold of no integrated contamination $\left(P_{c} \leq 0\right)$; hence, there is urgent need for remediation of the soil to avert ecological and human health disaster.

The assessment of the contamination level of the diagnostic species (A. gayanus) used in this study is presented in Figure 3.
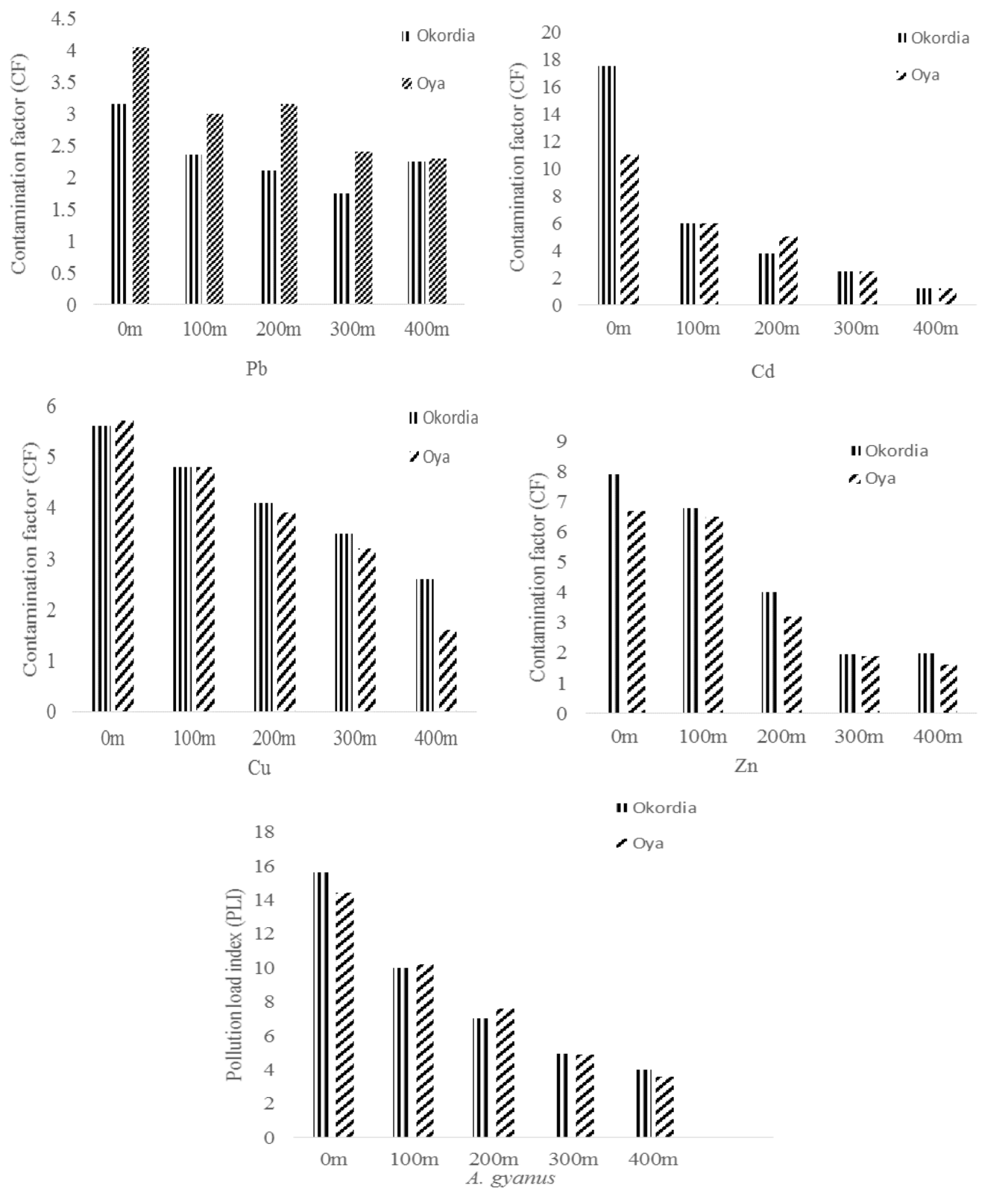

Figure 3. The contamination factor $(C F)$ of $(a) \mathrm{Pb},(b) \mathrm{Cd},(c) \mathrm{Cu},(d) \mathrm{Zn}$ and (e) the pollution load index (PLI) of A. gayanus in the 2 study sites.

The concentrations of $\mathrm{Pb}$ in A. gayanus at $0 \mathrm{~m}$, $100 \mathrm{~m}$ and $400 \mathrm{~m}$ in Okordia were within the slight contamination level. The same level of contamination was observed at $100 \mathrm{~m}$ and $200 \mathrm{~m}$ in Oya, while at $0 \mathrm{~m}$ 
the level of contamination of A. gayanus reached moderate contamination (Figure 3a). The concentrations of $\mathrm{Cd}$ in A. gayanus at $0 \mathrm{~m}$ and $100 \mathrm{~m}$ in Okordia and Oya reached the severe contamination level, while moderate contamination was observed at $200 \mathrm{~m}$ and $300 \mathrm{~m}$ in the 2 sites (Figure 3b). Cu concentrations in A. gayanus at $0 \mathrm{~m}, 100 \mathrm{~m}, 200 \mathrm{~m}$ and $300 \mathrm{~m}$ indicated moderate contamination, while slight contamination and suspected contamination were exhibited at $400 \mathrm{~m}$ in Okordia and Oya, respectively (Figure 3c). Moderate contamination of $\mathrm{Zn}$ was recorded in A. gayanus at $0 \mathrm{~m}, 100 \mathrm{~m}$ and $200 \mathrm{~m}$ in both Okordia and Oya, while at $300 \mathrm{~m}$ and $400 \mathrm{~m}$ suspected contamination of A. gayanus was exhibited (Figure 3d). The pollution load of the index of A. gayanus showed that all locations in the 2 sites were severely contaminated with heavy metals (Figure $3 \mathrm{e})$. This portends a grave ecological problem as food crops planted in this agricultural land can possibly accumulate metals to the levels that portend health implications to animals and humans that depend on them for survival.

\section{Conclusion}

The study has revealed that the several incidences of crude oil spillage have really impacted on the environment of Ikarama with heavy metals. The pollution indices of the soil at $0 \mathrm{~m}$ and $100 \mathrm{~m}$ were high, while the other distances $(200 \mathrm{~m}, 300 \mathrm{~m}$ and $400 \mathrm{~m}$ ) were of low pollution. The high metal pollution of the soil at all the distances was reflected on the diagnostic plants, as A. gayanus showed the severe metal pollution status due to uptake and eventual accumulation of metals to toxic levels in the biomass. It is obviously imperative that the government improve environmental policies to protect the Niger Delta from a degradation effect of oil exploration. It is also important that the Environmental Guidelines and Standards for the Petroleum Industry in Nigeria (EGASPIN) that stipulated that the spiller should be responsible for the clean-up of the site and restoration to the original state should be adequately empowered and enforced on oil prospecting companies in the Niger Delta to reduce the risk and hazard posed by heavy metals to humans and the ecosystem.

\section{Acknowledgements}

The authors express their appreciation to Prof. Oladele of the Department of Plant Biology, University of Ilorin for helping in reviewing the manuscript.

\section{References}

Ekundayo, E. O. \& Obuekwe, O. (2000). Effects of an oil spill on soil physic-chemical properties of a spill site in a Typic Udipsamment of the Niger Delta basin of Nigeria. Environmental Monitoring and Assessment, 60(2), 235-249.
http://dx.doi.org/10.1023/A:1006230025095.

Bada, B. S. \& Olarinle, T. A. (2012). Characteristics of soils and heavy metal content of vegetation in oil spill impacted land in Nigeria. In proceedings of the Annual International Conference on Soils, sediments, Water and Energy vol. 13, article 2.

Bouyoucos, G. J. (1962). Hydrometer method improved for making particle size analysis of soil. Soil Agronomy Journal 54(5), 464-466. http://dx.doi.org/10.2134/agronj1962.00021962005400 $050028 \mathrm{x}$

Canadian Council of Ministers of the Environment (CCME). (2007). Canadian soil quality guidelines for the protection of environmental and human health: summary tables. Canadian Council of Ministers of the Environment, Winnipeg. Excerpt from Publication No. 1299, ISBN 1-896997-34-1.

Daud, M., Khalid, N., Iqbal, J., \& Ahmad, S. (2006). Assessment of atmospheric pollution level using Asclepias procera leaves as biomonitor. Radiochim Acta 95, 423-431.

D’Souza, R., Varun, M., Pratas, J., \& Paul, M. S. (2013). Spatial distribution of heavy metals in soil and flora associated with the glass industry in north central India: implications for phytoremediation. Soil and Sediment: An International Journal 22(1), 1-20. http://dx.doi.org/10.1080/15320383.2012.697936.

Ekundayo, E. O. \& Obuekwe, O. (1997). Effects of oil spill on the physic-chemical properties of a spill site in a paleudult of the Niger Delta basin of Nigeria. Environmental Monitoring and Assessment, 60, 235249. http://dx.doi.org/10.1023/A:1006230025095.

Essoka, P. A., Ubogu, A. E., \& Uzu, L. (2006). An overview of oil pollution and heavy metal concentration in Warri area, Nigeria. Management of Environmental Quality: An International Journal, 17(2), 209-215. http://dx.doi.org/10.1108/14777830610650519.

Fernandez, J. \& Carballeira, A. (2001). Evaluation of contamination by different elements in terrestrial mosses. Archives of Environmental Contamination and Toxicology, 40, 461-468. http://dx.doi.org/10.1007/s002440010198.

Gideon, O. \& Josephine, E. (2008). Levels of heavy metals $(\mathrm{Pb}, \mathrm{Cd}, \mathrm{Zn}, \mathrm{Mg}$ and $\mathrm{Cu}$ ) in cassava from Niger Delta of Nigeria as an indication of soil environmental pollution. Journal of the Chemical Society, 2, 120-143.

Gonzalez-Miqueo, L., Elustondo, D., Lasheras, E., \& Santamaria, J. M. (2010). Use of native mosses as biomonitors of heavy metals and nitrogen deposition in the surrounding of two steel works. Chemosphere, 78, 965-971. http://dx.doi.org/10.1016/i.chemosphere.2009.12.028.

Gustav, R. (1974). Hazardous heavy metals (No. 6, p. 14). WHO International Reference Centre for Waste Disposal (IRCWD News)

Hart, A. D., Oboh, C. A., Barimalaa, I. S., \& Sokari, T. G. (2005). Concentrations of trace metals $(\mathrm{Pb}, \mathrm{Fe}, \mathrm{Cu}$ and $\mathrm{Zn}$ ) in crops harvested in some oil prospecting locations in River state, Nigeria. African Journal of Food Agriculture, Nutrition and Development, 5(2), 34-41.

Huang, R. (1987). Environmental pedology. Beijing, China: Higher Education Press.

Imoobe, T. O. \& Iroro, T. (2009). Ecological restoration of oil spill sites in the Niger Delta, Nigeria. Journal of Sustainable Development in Africa, 11(2), 54-65.

International Organisation for Standardisation (ISO). (2002). Soil quality-Extraction of trace elements soluble in agua regia (pp. 466). ISO 11. 
Joner, E. J., Hirmann, D., Szoler, O. H. J., Todorovic, D., Leyval, L., \& Liobner, A. P. (2004). Priming effects on PAH degradation and ectoxicity during phytoremediation experiment. Environmental Pollution, 128: 429-435. http://dx.doi.org/10.1016/j.envpol.2003.09.005.

Kalavrouziotis, I., Koukoulakis, P., \& Kostakioti, E. (2012). Assessment of metal transfer factor under irrigation with treated municipal wastewater. Agricultural Water Management, 103,114-119. http://dx.doi.org/10.1016/j.agwat.2011.11.002.

Kuruk, P. (2004). Customary Water Laws and Practices in Nigeria. Retrieved from: http://www.fao.org/fileadmin/ templates/legal/docs/CaseStudy_Nigeria.pdf (Accessed 23 November, 2014)

Ling, W., Shen, Q., Gao, Y., Gu, X., \& Yang, Z. (2007). Use of bentonite to control the release of copper from contaminated soils. Australian Journal of Soil Research, 45(8), 618-623. http://dx.doi.org/10.1071/SR07079.

Ministry of Environment (MOEN) (2008). Oil spill logbook investigated (pp. 10). Ministry of Environment, Bayelsa state, Nigeria.

Nduka, J. K., Obumselu, F. O., \& Umedun, N. L. (2012). Crude oil and fractional spillages resulting from exploration and exploitation in Niger-Delta region of Nigeria: A review about the environmental and public health impact. In M. Younes (Ed.) Crude oil exploration in the world.

Ngobiri, C. N., \& Ayuk, A. A. (2007). Anunuso II. Differential degradation of hydrocarbon fractions during bioremediation of crude oil polluted sites in Niger Delta area. Journal of Chemical Society of Nigeria, 32, 151158.

Nolan, K. (2003). Copper Toxicity Syndrome. J. Orthomol. Psychiatry, 12(4), 270-282.

Odu, C. T. I., Nwoboshi, L. C., \& Esuruoso, O. F. (1985). Environmental studies (soils and vegetation) of the Nigerian Agip Oil Company Operation Industry and the Nigerian Environment (pp. 274-283). Lagos, Nigeria: NNPC.

Osuji, L. C., \& Nwoye, S. C. (2007). An appraisal of the impact of petroleum hydrocarbons on soil fertility: the Owaza experience. African Journal of Agricultural Research, 2(7), 318-324.

Ozurumba, C. C. (1999). Effects and causes of oil spillage. National Association of Petroleum Explorationist Bulletin, 14, 31-45.

Sauve, S., McBride, M. B., Norvell, W. A., \& Hendershot, W. H. (1997). Copper solubility and speciation of in situ contaminated soils: Effects of copper level, $\mathrm{pH}$ and organic matter. Water, Air and Soil Pollution, 100, 133149.

http://dx.doi.org/10.1023/A:1018312109677.

State Environmental Protection Administration of China (SETAC). (1995). Chinese Environmental Quality Standard for Soils (GB15618-1995). Beijing, China: author.

Varun, M., D’Souza, V., Pratas, J., \& Paul, M. S. (2012). Metal contamination of soils and plants associated with the glass industry in north central India: prospects of phytoremediation. Environmental Science and Pollution Research, 19, 269-281. http://dx.doi.org/10.1007/s11356-011-0530-4.

World Health Organization (WHO). (1996). Permissible limit of heavy metals in soil and plants. Geneva, Switzerland: author.

Young, R. A. (2005). Toxicity Profiles: Toxicity Summary for Cadmium, Risk Assessment Information System.
RAIS, University of Tennessee Retrieved from: http://rais.ornl.gov/tox/profiles/cadmium.html. 


\title{
Dirvožemio taršos metalais ir diagnostinių biologinių rūšių, susijusių su naftos išsiliejamais ịvertinimas Nigerio deltoje, Nigerijoje
}

\author{
Paul O. Fatoba, Clement O. Ogunkunle ir Cynthian O. Ihaza \\ Aplinkos biologijos skyrius, Augaly biologijos departamentas, Ilorin universitetas, Nigerija
}

(gauta 2015 m. birželio mèn.; priimta spaudai 2015 m. liepos mėn.)

\begin{abstract}
Šiame tyrime buvo įvertintas žaliavinès naftos išsiliejimų ekologinis poveikis aplinkai Nigerijos Nigerio deltos bendruomeneje, kurioje gausu naftos išteklių. Buvo paimti viršutinio dirvožemio $(0-15 \mathrm{~cm})$, vidutinio dirvožemio $(15-25 \mathrm{~cm})$ ir vyraujančių rūšių - Gamba žolès (Andropogon gayanus) - bandiniai, naudojant skersinio pjūvio metodą tuose taškuose, kuriuose buvo išsiliejusi nafta. Bandiniai taip pat buvo paimti iš nepaveiktų vietų (kontrolei). Bandiniai buvo šlapiai kompostuojami ir buvo nustatytos $\mathrm{Pb}, \mathrm{Cd}, \mathrm{Cu}$ ir $\mathrm{Zn}$ koncentracijos, naudojant liepsnos atominę absorbcijos spektrometriją, o viršutinio dirvožemio fiziko-cheminès savybès buvo nustatytos standartiniais metodais. Informacija buvo panaudota Studento t-testui, ANOVA ir Pearsono koreliacijos analizei atlikti, o taršos įvertinimo modeliai buvo panaudoti nustatyti dirvožemio ir augalų rūšių taršos dydį. Rezultatai parodè, kad $\mathrm{Pb}, \mathrm{Cu}$ ir $\mathrm{Zn}$ koncentracijos viršutiniame dirvožemyje viršijo tarptautinius standartus netoli išsiliejimų esančiose vietose $(0-200 \mathrm{~m})$, o Cd koncentracijos tarptautinius standartus viršijo visose vietose. Vidutiniame dirvožemyje tarptautinius standartus viršijo tik $\mathrm{Cd}$. Užterštumo $\left(P_{i}\right)$ ir Integruotos taršos $\left(P_{c}\right)$ viršutinio dirvožemio rodikliai parodè mažèjančią tendenciją: taršos vietose $(0-100 \mathrm{~m})$ buvo didelè $P_{c}$, o $200 \mathrm{~m}$ atstumtu - visų metalų $P_{c}$ buvo vidutinè. $\mathrm{Pb}$ ir Cd dydžiai diagnostinèse biologinėse rūšyse viršijo Pasaulinès Sveikatos organizacijos standartus ir Taršos apkrovos rodiklis (PLI) parode didelę taršą. Apibendrinant, žaliavinès naftos išsiliejimų poveikis buvo žymus, todèl dirvožemio sutvarkymas yra svarbus, kad būtų išvengta ekologinès ir žmonių sveikatos katastrofos. Be to, šios išvados yra naudingos projektuojant vietos aplinkos kontrolei skirtoms strateginėms priemonėms.

Raktiniai žodžiai: naftos išsiliejimas, integruotas taršos rodiklis, dirvožemio sutvarkymas, taršos apkrovos rodiklis.
\end{abstract}

